\title{
“Upbuilding Examples" for Adults Close to Children
}

\author{
Stein M. Wivestad
}

Published online: 16 September 2012

(C) The Author(s) 2012. This article is published with open access at Springerlink.com

\begin{abstract}
Both in formal situations (as school teachers, football trainers, etc.) and in many, often unpredictable informal situations (both inside and outside institutions) —adults come close to children. Whether we intend it or not, we continually give them examples of what it is to live as a human being, and thereby we have a pedagogical responsibility. I sketch what it could mean to let ourselves "be built up", in a Kierkegaardian sense, on the foundation of unconditional love, presupposing that this love is possible for all human beings. Kierkegaard's Upbuilding discourses invite each reader to engage in a dialogue with the possibilities in the text. Thereby the reader may become aware of his or her present situation in life and see possible alternatives. These discourses or "talks" (taler in Danish) exemplify a manner of indirect communication which perhaps may be transferred to encounters with works of art in general: How could I let examples in literature, pictures, films and music invite and challenge me - to ask myself who I am right now and who I ought to be? My aim is to present an alternative to the instrumental advices that adults are given today. I attempt to clarify the leading concept "upbuilding examples", sketch the difference between upbuilding, education and Bildung, refer to works of art that seem to have upbuilding possibilities, and consider why upbuilding examples should be studied and how they could be studied in small self-governed groups of adults.
\end{abstract}

\section{Vision and Sources}

Dostoevsky has a thought-provoking comment to adults in The Brothers Karamazov:

You pass by a little child, you pass by, spiteful, with ugly words, with wrathful heart; you may not have noticed the child, but he has seen you, and your image, unseemly and ignoble, may remain in his defenceless heart. You don't know it, but you may have sown an evil seed in him and it may grow, and all because you were not careful before the child, because you did not foster in yourself a careful, actively benevolent

S. M. Wivestad $(\bowtie)$

Department of Education, Norsk Lærerakademi University College, PO Box 74, 5812 Sandviken,

Bergen, Norway

e-mail: sw@nla.no 
love. Brothers, love is a teacher; but one must know how to acquire it, for it is hard to acquire, it is dearly bought, it is won slowly by long labour. (Dostoevsky 2000, VI

$3 g$, p. 298)

Adults come close to children in formal as well as informal situations. If we, like the adult in the example above, do not see how we influence children, we might harm them. Children are vulnerable, they may be more sensitive than we would like to think, and if we want human life to continue in a good way, we ought to be good exemplars, or at least not really bad ones. That may demand "long labour" and patience. What can we do? Perhaps the possibilities are very restricted? If something is possible, even small steps should be considered. We may be moved both by principles and by people. Good examples give us models to emulate. Bad examples may warn us and help us to avoid becoming people who unintentionally are "sowing an evil seed" in the child. There are several ways which might open possibilities for small corrections and improvements: direct experiences, research, discussion forums on the internet, courses in parenting, courses in leadership, studies in ethics and education. A way that I see as a promising supplement to these established ways, would be to encourage adults to form pedagogical groups, where examples in literature, pictures, films and music could be experienced and talked about. My vision is that the participants in such groups could try and help each other to become "better human beings" (Wivestad 2012) - persons who seek and do what is good and avoid evil. I do not claim that persons in this way actually will become "better", but I argue for some good possibilities that can be actualised when informal small groups of adults engage in serious encounters with works of art. The saying above is from Father Zossimah, the mentor of the youngest of the brothers Karamazov. He gives a direct challenge to adults in the novel, and indirectly we, the readers, can let ourselves be challenged as well. Perhaps some would label the challenge as "narrow and moralistic". This label may be questioned when we consider how Father Zossimah understands the challenge: "Brothers, have no fear of men's sin. Love a man even in his sin, for that is the semblance of Divine Love and is the highest love on earth" (Dostoevsky 2000, p. 297). The love that the adult in the example above had not fostered in himself, is a love for all, not a love that is reserved only for those who are lovable. This love is a possible "teacher" for all who are willing to be taught by it and to give it authority in their lives (Biesta 2012). Such teaching is probably most difficult to receive for those who are proud of their virtues and competences. If we let love be our teacher and struggle with ourselves to acquire "careful, actively benevolent love", the struggle in itself is a good model for the children-even when we fail.

My interest in personal and political improvement is linked to a concern with the practical "upbringing" (Wivestad 2012) of children. Upbringing is a universal human phenomenon and therefore more fundamental than schooling. As the way of young people is dependent on their way as children, the youth's formal education is dependent on their upbringing from the very beginning; and as our good intentions in the upbringing of children can be contradicted by the example we give them, both formal and informal educators ought to be more aware of the fact that they are models. The upbringing of children challenges us to live what we learn, and when failing, to struggle with ourselves. The struggling adult is a better exemplar than the seemingly perfect one, because the latter loses the child's trust when the adult's bad sides are exposed.

In the attempt to flesh out the vision, firstly I found help in Aristotle's reference to examples (like Pericles) when he defines moral virtue (arete) and moral wisdom (phronesis) (Aristotle 2002, 1107a1, 1140a24, 1140b8), and in Thomas Aquinas's ideas of a fruitful relation between moral wisdom and unconditional love (Wivestad 2008). Other 
impulses have been: Paulo Freire's well-formed aim of creating "a world in which it is easier to love" (Freire 1972, p. 19), the plans of Comenius (1986) for a pan-paideia, a universal paideia (upbringing, cultural heritage and Bildung) inviting all human beings (pantes) to be taught about the universe (panta) in a thorough (pantos) way, Pestalozzi's (1825) and MacIntyre's (1999) ideas of a grass-root movement in the local community, Kierkegaard's (1990, 1995) challenging texts on upbuilding in love, Hans-Georg Gadamer's understanding of art experience as self-understanding (Gadamer 1986) and insistence on experience as insight in one's own limitation, one's finitude (Gadamer 1965); Eisner's (1991) ideas for an artistic pedagogical inquiry, and Mollenhauer's (1994) sketch of a critical "universal pedagogic" (Allgemeine Pädagogik).

Mollenhauer helps us to see that important documents (pictures and literary texts) in the Western cultural tradition remind us of connections which are easily forgotten in the modern scientific specialization, connections which nevertheless form a necessary basis for reasonable choices today. Artistic and scientific sources may supplement each other, and views derived from the context of the local community, with its particular cultural traditions, should be coordinated with a global perspective. As Adam's descendants, we are able to give names to all the animals (Dylan and Arnosky 2010) and to all beings. We are probably the only species that can view every small element in the universe as part of the totality, and therefore we ought to care for all beings. But it is the children close to us who are our primary responsibility.

\section{What is an "Upbuilding Example"?}

The adjective or adverb "upbuilding" I found via Tubbs (2005, chapter 8) and a translation of Søren Kierkegaard's Opbyggelige taler. ${ }^{1}$ Something is opbyggelig or "upbuilding" when it builds up our "house", i.e. our life (Wivestad 2011, p. 616). The upbuilding discourses have been assessed as "the keystone" of Kierkegaard's authorship (Perkins 2003, p. 2), but it seems that they are not well known by philosophers. Perhaps some have thought them relevant only for people who understand themselves as Christians? Kierkegaard displays "a kind of writing that repeatedly attempts to turn readers back to themselves and to their individual situation vis-à-vis God" (Pattison 2002, p. 88). He seems thus to actualise the Socratic "know yourself" in relation to "the eternal", and he searches for a kind of truth that is "concerned" (Kierkegaard 1990, p. 233)—somewhat like the Nicomachean ethics, where the intention is to disclose truth that can help us "become good, since otherwise the inquiry would be of no benefit to us" (Aristotle 1985, 1103 b29 and 1140b5). What can build up my life? Can we who are temporal beings understand ourselves and live in truth if we do not wonder how the temporal is related to what is not temporal? In Being and time Heidegger has remarked: "there is more to be learned philosophically from his [Kierkegaard's] 'edifying' writings, than from his theoretical ones-with the exception of his treatise on the concept of anxiety" (Heidegger, quoted in Pattison 2002, p. 1). The concept 'upbuilding' in these writings comes from

\footnotetext{
${ }^{1}$ Kierkegaard's (1990) Eighteen upbuilding discourses are translated by E. H. Hong \& H. V. Hong. Kierkegaard discusses the concept "upbuilding" in his book Works of love (1995), which is also translated by the Hongs. A good selection of Kierkegaard's upbuilding discourses and Christian discourses are made by George Pattison (Kierkegaard 2010). He has wanted to make these writings accessible to contemporary readers, contending that Kierkegaard's vision of life, with Gift, Creation and Love as keywords, invites all to a dialogue about what can "build us up in gratitude for the gift of being, in joy at being who we are, and in love for love itself" (p. xxvii).
} 
Christian traditions. It is seldom used in today's dominating post-Christian culture, and if it is used, it is sometimes used ironically. By choosing upbuilding as a leading concept I express Kierkegaard's and my own connection to Christian traditions. This may prompt the question: Can upbuilding be relevant to agnostics and atheists? In his introduction to a selection of Kierkegaard's Spiritual writings, George Pattison contends that Kierkegaard's interpretations of the Bible "restates Christian teaching in a way that can speak to those of all faiths and none" (Kierkegaard 2010, p. xxvii). Kierkegaard assumed only that his readers were "concerned about the meaning of their life in the world", and that they were "ready to take seriously the possibility of religion" (p. xv). Following this line of thought, I will search for upbuilding examples not only in Christian traditions. To clarify what I mean by an "upbuilding example", I will start with an example from an artist who explicitly wants to give "a global idea-image of the human" (Vasarely 1982, p. 9). ${ }^{2}$

Before reading on, please study the picture below. What do you see in this picture?

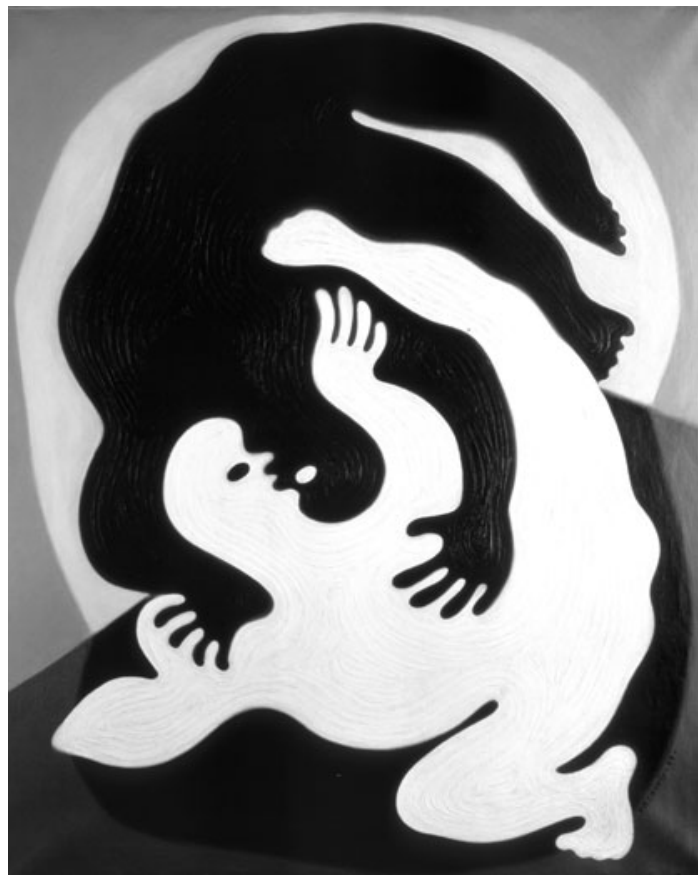

To me, the picture of Vasarely, Catch from 1945, represents two flat human figures, one black and one white; or is it rather two sides of the same person? The figures complement each other. Perhaps they confront each other as well? The hands are in focus. How do they "catch"? Do the hands embrace or push? What are the differences between the legs of the two figures? How do the figures move? The composition can give associations to a kind of dynamic balance, in the same way as Yin and Yang. Different interpretations of Catch might be possible. Perhaps the work represents human life as a life of inevitable contradictions and tensions, a life that challenges us to self-reflection? Perhaps it tells about a life where we have to struggle with identity and integrity problems? Perhaps it challenges us to embrace ourselves as split in two, and if so, to understand what characterizes the

2 Je me suis efforcé de dépersonnaliser le contenu, de tenir compte de toutes les vérités, de donner une idéeimage globale de l'humanité. 
difference between our two parts? An exploration of this picture could be a starting point for a dialogue about different possible basic realities of human life. Facing the realities of our life I see as a necessary starting point for upbuilding, and therefore I understand this picture as an upbuilding example.

However, why talk about "upbuilding"? Could not this exploration and dialogue be understood in more traditional ways, for instance as a process of Hegelian Bildung, where one tries to "seek one's own in the alien, to become at home in it" (Gadamer 1979, p. 15), or as an "educative experience", where we in the continuum with our previous experiences form an attitude of "desire to go on learning" (Dewey 1988, p. 29)? Both these traditions attend to important points that could build up both the person and the fellowship. The human consciousness cannot have or undergo new experiences unless it is turned aroundaway from the illusions (Plato 2000, 7.515c-d) - unless it "recognizes itself in what is alien and different" (Gadamer 1979, p. 318). Is Bildung and education sufficient? "Bildung, as being raised to the universal" (p. 13) or to Deweyan endless growth, might miss out what both Dostoevsky and Kierkegaard see as the highest, i.e. the love of the neighbour. Kierkegaard's Danish contemporaries talked about Dannelse (a word that can be translated with formation and Bildung and liberal education) as a cry for "the highest", and there seems to be a similar cry today. Kierkegaard argues why it is not enough to be dannet or "cultured":

Are you, my listener, perhaps what is called a cultured person? Well, I, too, am cultured. But if you think you will come closer to this highest with the help of "culture" ["Dannelse"], you make a great mistake. ... has anyone's zeal for becoming cultured [vinde Dannelse] taught him to love the neighbor? Alas, have not this culture [Dannelsen] and the zeal with which it is coveted rather developed a new kind of distinction, the distinction between the cultured and the uncultured? ... Of course, a certain social courtesy, a politeness toward all people, a friendly condescension toward inferiors, a boldly confident attitude before the mighty, a beautifully controlled freedom of spirit, yes, this is culture-do you believe that it is also loving the neighbor? The neighbor is the one who is equal. The neighbor is neither the beloved, for whom you have passion's preference, nor your friend, for whom you have passion's preference. Nor is your neighbor, if you are a cultured person, the cultured individual with whom you have a similarity of culture-since with your neighbor you have the equality of a human being before God. (Kierkegaard 1995, pp. 59-60).

The Bildung that persons may win (vinde) in the competition on the school arena, and the profit that nations may win on the global arena, may create rigid positions of inferiority and superiority, especially if one believes that the positions are deserved. Callous and rigid attitudes hamper the continuity of experience. Such attitudes will be "mis-educative" (Dewey 1988, p. 17) because they hinder the possibility of further growth. Kierkegaard does also differentiate between Dannelse and Misdannelse, but his focus is the avoidance of hatred, strife and revenge between human beings, who, in his perspective, in reality are equal, in spite of all outward distinctions. Therefore he maintains that upbuilding - as a work of love-is a necessary condition for education: "education without the upbuilding is, eternally understood, miseducation. ... But like love, upbuilding, if possible, will unite those, who are most different from each other, in the essential truth" (Kierkegaard Papirer 1918, VIII 2 B, lines 11-12 and 16-17, translated in Søltoft 2000, p. 22).

What is an "upbuilding example"? Kierkegaard has presented several good examples in his Eighteen upbuilding discourses (1990). These beautiful texts may help the reader in an 
indirect way to see what builds us up as human beings. A summary of them may be misleading. Form and content is intertwined in Kierkegaard's writings: "it is precisely the stylistics of the upbuilding discourses that will provide some of the most important clues to their philosophical significance" (Pattison 2002, p. 7). It is the encounter between possibilities in the texts and the reader's own life experiences that can make them important. However, because I want to select other works of art that have an upbuilding potential, I need some short direct guidelines, even if they only convey "shadow pictures" of the educational possibilities in the discourses. I derive these guidelines from Nigel Tubbs's interpretation of Kierkegaard (Tubbs 2005, chapter 8) and my reply to him (Wivestad 2011), especially the outline of how Kierkegaard's thinking can be educationally relevant (pp. 614-615), and the interpretation of stages in upbuilding (pp. 617-619). These may be compared with Pattison's (2002, pp. 37-38) description of the stages. Three summary points might give some understanding of upbuilding.

Something is upbuilding if

1. it helps us to a realistic understanding of our own limitations, helps us to acknowledge that we, in our striving to possess the world and become masters, will also be possessed by the world and thereby lose ourselves,

2. it helps us to see that our life as a whole is a good gift that we have been given,

3. it helps us to view others without hatred, envy and egoistic calculation, helps us to share with others the good gifts that we have been given.

I will give some comments to and concretizations of these three points.

Point 1 This follows the insight that Socrates derives from the saying at Delphi, that no one is wiser than Socrates: "the god is really wise ...'Human wisdom is of little or no value"" (Plato 1966, 21a and 23a-b). It is dangerous if hubris leads us to forget our finitude and imperfection. We and those close to us may suffer if our own knowledge and wisdom becomes our god, something that we trust absolutely. A classical play that reminds us of this, is Sophocles' Antigone (Wivestad 2008, p. 311). In the film Casino royale (Campbell 2006), which is based on the first Ian Fleming novel about James Bond, the hero is vulnerable. He is nearly tortured to death, and he enters a real love relationship which makes him ready to leave his "business" as agent 007. He loses his love, however, and perhaps therefore also his vulnerability. A series of other Bond films follows a pattern, which ends with outward success - in business as well as in bed. Books and films with protagonists who are always successful can move us away from a true understanding of ourselves, but could perhaps have upbuilding potential if read or seen in a critical way.

Point 2 This challenges the centre of a common modern understanding of human beings: We do not want to accept our life just as it is given to us and try to be autonomous architects of our life. We ourselves want to mend the split that we feel between how we are and how we ought to be, and we want to do it "on our own terms" (Kierkegaard 2010, p. xxi). Works of art like Munch's (1893) painting The scream, Pink Floyd's (1979/1994) concept album The wall and Kieslowski's (1988) film series Dekalog may help us to reflect realistically on our possibilities here. Films and games like Star Wars could be used for reflection, but can function as noise, a way to escape from encounters with our uncertainty, anxiety and doubt. If Kierkegaard is right, our best abilities and efforts are always imperfect, and the only possible foundation for upbuilding would be the love that has been given unconditionally to all.

Point 3 In Works of love (1995, pp. 212-219) Kierkegaard describes the foundation of upbuilding as unconditional love, a love that can bind people together in spite of the 
differences between them. This gives an important demarcation. All kinds of communication, formation and education that separate people from each other and lead to haughtiness and envy, are not building us up. Knowledge may be important, and the love that builds up is not without knowledge, but knowledge without love only "puffs up" (Kierkegaard 1995, p. 215). Love builds up and it builds up love: "Love is the ground, love is the building, love builds up" (p. 216). The foundation is given. "Love builds up by presupposing that love is present in the ground; therefore love also builds up where, in the human sense, love seems to be lacking" (p. 219). For Kierkegaard the foundation is a love that "has been present in every human being ever since creation"; and everyone has got this foundation, because we are created by God, who is love (Søltoft 2000, p. 25). A successful teacher points to the success of her student; politicians point to their country's success on PISA rankings and are proud of what has been built up. This is not the way love builds up. "A person can be tempted to be a builder, a teacher, a disciplinarian because this seems to be ruling over others; but to build up the way love does cannot tempt, because this means to be the one who serves ... love that builds up has nothing to point to, since its work consists only of presupposing" (Kierkegaard 1995, p. 217). Nobody is tempted to become a servant. Serving the other in love means that we forget ourselves. Presupposing a foundation of love in the other, means that the building process goes on beyond our knowledge and control.

One of Kierkegaard's discourses that could be read individually and discussed in a group of adults, has the title Love will hide a multitude of sins (Kierkegaard 1990, pp. 55-68; 2010, chapter 11). When we focus on sin, sin is "fruitful". One sin gives birth to many more and becomes a "multitude of sins". But when we presuppose love in the other, we can ignore (hide) the bad sides of the other. This has obvious consequences for how we look at the other, how we listen to the other and how we include the other in our fellowship and care. As a positive example Kierkegaard refers to the parable of the father who waits for his youngest son to return (Luke 15:11-32). Similar works of art can have upbuilding possibilities: the Largo movement from Bach's (1731) Concerto for 2 violins in $d$-minor, where the two main voices "wait" for each other and "embrace" each other, Rembrandt's (1668) painting The return of the prodigal son, Kieslowski's (1993) film Blue, and the animation film Tokyo godfathers (Kon 2003). The latter example presupposes love in a rebellious teenager, an alcoholic and a drag queen.

Some examples unite many in a celebration of self-love that can lead away from fellowship. I can't get no satisfaction (Jagger and Richards 1965) has a self-centered text connected to a repeated riff that moves around itself. The song expresses a feeling of alienation towards the dominant culture, but bows to the consumption of pleasures: easy information, special cigarettes (hash?), and girls who easily can be "made". The restless consumer and capitalist, who never gets satisfaction, seems to adore an unholy trinity of consumption as Life-giver, competition as Saviour and culture industry as Comforter. Films, books and games in the Walt Disney franchised series Pirates of the Caribbean move their characters and participants to egoistic calculation. The principle is expressed in this pregnant mantra: "Take what you can, give nothing back!"

In the Norwegian short novel A happy boy, Eyvind has his mother and his schoolmaster as good models. "Eyvind grew and became an active boy: at school he was amongst the first, and he was capable at his work at home. That was because at home he was fond of his mother and at school he was fond of his master" (Bjørnson 1860/1896, ch. 3, p. 20). Before Baard became a schoolmaster, he made some fatal mistakes, and he had experienced great sorrows. But he was met with love and wanted to "pay it forward" to the school children. 
What influenced Eyvind most during his school years was the life story of his schoolmaster, which "his mother told him one evening as they sat by the fire. It ran through all his books, underlay every word the schoolmaster said; he felt it in the air of the schoolroom when all was quiet. It filled him with obedience and respect, and gave him a quicker apprehension, as it were, of all that was taught him" (p. 20). The situation changed when Eyvind approached the time of confirmation and the passage to adult status. Then he isolated himself and studied for his own prestige and power. It increased his knowledge, but decreased his love and joy. In the light of Vasarely's Catch and Kierkegaard (1990, pp. 314-319), Eyvind's situation can be described as a struggle between the first self and the deeper self. The first self wants to eat the fruits of knowledge, possess the world and become master; while the deeper self shows him that this world is dubious, inconstant and deceitful. This creates conflict, and the result may be that the first self "kills" the deeper self by drowning it in oblivion or noise. The schoolmaster had to take a risk when he stopped Eyvind on his lonely way to "success", appealing to Eyvind's deeper self. And Eyvind let himself be stopped; he acknowledged his greed for power and his lack of gratitude towards his parents, his teacher and his God. So in the end Eyvind stood for confirmation as number one-without vanity.

Some examples remind us of the vulnerability of the children and how that challenges our life style. In the film L'Enfant, directed by the brothers Jean-Pierre et Luc Dardenne (2005), we observe how Sonia, a girl in her late teens with a newborn baby in her arms, crosses streets with dangerous motor traffic. Sonia has a flat, but her boyfriend Bruno has let it out for some days to another couple while she was in the hospital. She searches for Bruno, and gets the help of a boy who lets her sit on the backseat of his moped with the baby in her arms. When she finds Bruno, he is more interested in his own petty criminal activities than in the baby. The film does not let us know anything of what has happened before and during Sonia's pregnancy, but it is quite obvious that Bruno is not prepared to be a father. Though he shows "cleverness" - an ability to attain his goals (Aristotle 1985, $1144 \mathrm{a} 25$ Irwin), this force is even more alarming, because he is at the same time immature - choosing sometimes to act justly (in his dealings with some schoolboys who steal for him) and choosing sometimes to lie. He seems to be "guided in his life and in each of his pursuits by his feelings" (1095a7). We do not get insight into his upbringing, but he is not welcomed in his mother's house, when he wants his mother to give him a false alibi. However, Sonia loves Bruno. She is childlike in a positive way-lively, playful and humorous, and is at the same time caring and responsible, both in her relation with the child and with Bruno. She leads Bruno to be registered as the child's father and proposes that he should apply for a job. She asks Bruno to walk the child, Jimmy, with the pram. During the walk he gets an idea: The person who receives his stolen goods had mentioned to him the possibility of adoption for money. He follows this impulse, and like in a documentary, we witness how an illegal adoption may be brought about. In his first direct contact with the child, however, we notice Bruno's care when he puts the child down, and sense that he perhaps has mixed feelings. But he does not stop the process. They need the money, and to him it seems easy to "produce" a new baby. When Sonia is confronted with the facts, she faints and has to be brought to hospital. When she wakes up, she tells the truth. The police investigate the case, but Bruno lies as usual in problematic situations, even accusing Sonia for telling lies about him. Bruno realizes that he has done wrong. He manages to get the child back again from the criminals, but Sonia will not talk with him, and throws him out of the flat. The film ends, however, with a positive possibility. When one of the young boys who steal for him is caught by the police, Bruno admits responsibility and guilt. In the last scene Sonia visits him in prison. The end gives hope: His 
feeling of shame and Sonia's love can perhaps move him to turn around from his previous lifestyle. L'Enfant is an engaging and beautifully filmed story about the risks that a newborn child (and older children as well) may be exposed to by an immature adult. It also shows a possible way out of this. Children are dependent on adults who love them, adults who give without conditions, who see the real needs of each unique child there and then, and who make wise long-term decisions on behalf of the child.

What do I mean by an "upbuilding example"? Three points are important: First, an upbuilding example is concrete and perceptible and emotionally engaging - it may be a person, a picture, a story, a text, a song, a film—it is an artistically crafted work that is easy to remember, easy to learn by heart. Second, an upbuilding example may help us to see truths about ourselves and our world - often very unpleasant truths. ${ }^{3}$ Third, an upbuilding example may contribute to our upbuilding in love. The foundation for this upbuilding is a gift of love to all people, whether they see it as God's gift or not. It is a gift which is given without conditions and which we ought to share with each other without conditions.

\section{Why Should Upbuilding Examples be Studied?}

It has been argued by a Norwegian philosopher, Peter Wessel Zappfe, that the best future for the world as a whole would be a planned voluntary and gradual extinction of the human species; each couple having no more than one child (Zapffe 1983/1941, §59, p. 240). However, even in this extreme view, each child who is conceived ought to be welcomed to this life. Then the first educational question could be: Why do we want this child? The question can be addressed to the adult generation as a whole. Klaus Mollenhauer asks: "Warum wollen wir Kinder?"/"Why do we want children?" (Mollenhauer 1994, p. 17). When I stand with a newborn child in my arms, the salient moral questions are: What example of human life do I want to give this child, and will the example that I want to give also be good for this unique child?

Why can examples be important? Why should adults study works of art? And what are the possibilities in the study of works of art for those who want to struggle with themselves as exemplars for children? In the Kantian tradition actions are justified by universal principles. In the Aristotelian tradition those who are virtuous will intuitively seek the right thing to do and choose their actions through engaged deliberations and judgments in each particular situation. Examples are important in both these traditions. We need examplesstories, images and metaphors to live by, and we need principles when we evaluate these examples (Louden 2009, pp. 77-78). Kant "regularly recommends the use of examples in education" (Løvlie 1997). They have a didactic function and help us to see that "fulfillment of the moral law is a real possibility... not just a logical possibility" (Guyer 2012, p. 124). In the Aristotelian tradition examples are even more important. The starting point for Aristotle is not an abstract theory of perfect morality, but concrete human exemplars that we respect and admire because they are relatively good persons. Experiences of good and bad human qualities do not depend on our ability to give verbal justifications of those qualities. From the very beginning children will experience and feel whether the adult persons around them in general do well or bad. So it is, also when we as adults experience a convincing work of art. In the grip of a good work of art, "we are fully present to the work,

\footnotetext{
3 Those who understand teaching as a gift "do not shy away from difficult questions and inconvenient truths", but "welcome the unwelcome" (Biesta 2012).
} 
and 'get' all its features as a whole" (Arcilla 2010, p. 51). "We are thereby convinced by it” (p. 52)-it engages our emotions directly.

According to the Aristotelian tradition, you can act wisely without being wise yourself. The decisive moral action is to listen to and to emulate persons who are wise. Virtue, human excellence, the way we should hold ourselves between too much and too little, is determined rationally and "in the way which the wise person would determine it" (Aristotle 2002, 1107a1 Rowe). Pericles is a typical exemplar, because persons like him "are capable of forming a clear view of what is good for themselves and what is good for human beings in general" (1140b9). By studying critically those who are wise and by emulating their examples in a creative way, we may do the right thing and gradually acquire virtuous ways of holding ourselves, even before we are able to formulate verbally the reasons for what we do. Works of art cannot replace such living exemplars, but may give an important supplement, especially because we, through works of art, may become aware of many possibilities that we can learn not to emulate. This is why Aristotle thought that the study of tragedies like Antigone was important (Wivestad 2008, p. 311). His aim was not to "know what virtue is, but to become good" (Aristotle 1985, 1103b29).

Abstract principles and recipes may be helpful, but they have to be adjusted to the particular circumstances in new situations. Even instrumental Supernanny principles for retaining self-control when you get angry (Samuel 2007) can have some strength when they are supplied with the presentation of cases. Some cases just illustrate and confirm the principles. Through the study of a unique case, however, we may have a new experience. Works of art may be seen as an enormous collection of unique cases. Such cases open possibilities for exploring personal development and relationships in more depth than usual. Each work of art can modify our previous experiences: "it is not... as we thought" (Gadamer 1979, p. 318). The study of unique cases makes possible a kind of spiritual exercise whereby we learn to live and to die. We can give attention to particulars-looking for important nuances. We can meditate on negative possibilities and become open for dialogue on important questions (Hadot 1995, pp. 84-89). "But everything that touches the domain of the existential... is not directly communicable.... That is why it often happens that a poem or a biography are more philosophical than a philosophical treatise, simply because they allow us to glimpse this unsayable in an indirect way" (p. 285).

Arts can be seen as metaphors for basic attitudes and "otherwise unspoken and unexamined assumptions" in any culture, and also as "a way of transcending" these assumptions (Small 1996, p. 2). Each different art may transfer something special about human possibilities that can neither be expressed in ordinary language nor in the other arts. Therefore all art forms could be relevant, and examples in literature, pictures, music and films could be supplied by examples in other art forms.

Some educational writers have shown how educators can learn from pictures (Mollenhauer 1994), others have supplied this with fiction and feature films (Arcilla 2010; Friesen and Sævi 2010), and there is a long tradition of fruitful contact between literature and education. Thomas Mann's narrator in the novel Doctor Faustus postulates an inner connection between good reading (bonae litterae) and the upbringing (Erziehung) of the young. The study of languages or humaniora, combined with the passion for the humanior (the more human) as a "living and loving sense of the beauty and rational dignity of human beings" (Mann 1980, p. 16, my transl.), ${ }^{4}$ destines the scholar in philology almost naturally to become an educator of the youth (Jugendbildner). Music, however, seems for him to be

\footnotetext{
4 inneren und fast geheimnisvollen Zusammenhang des altphilologischen Interesses mit einem lebendigliebevollen Sinn für die Schönheit und Venunftwürde des Menschen ...
} 
separated from this rational sphere of "unconditional trust in things of reason and human dignity" 5 and to represent a dangerous but possibly seminal influence of the underworld (unteren Gewalten).

Warnings like this may perhaps be relevant if our destination is simply to become just and rational beings. But if we are emotional beings and if the emotions are "essential elements of human intelligence" (Nussbaum 2001, p. 3), if the wisdom of the head is not "all-sufficient" (Dickens 1989, p. 297), but needs to be complemented with a wisdom of the heart, we should search for upbuilding examples in music as well as in literature. In his Politics Aristotle (1997, 1340a23) refers to a common experience: we are moved and "undergo changes in our soul" through rhythms and melodies. If the movement of musical structures have a likeness to specific emotions, then it is possible that music may build up and strengthen emotional habits. Thereby music, which is entertaining and pleasurable in itself, may be helpful in character formation.

Nussbaum (2001, p. 254) thinks that music is connected to "the perception of urgent needs and vulnerabilities that are often masked from view in daily life". She quotes from a letter that the composer Gustav Mahler wrote in 1896: "As long as my experience can be summed up in words, I write no music about it; my need to express myself musicallysymphonically - begins at the point where the dark feelings hold sway, at the door which leads into the 'other world' - the world in which things are no longer separated by space and time" (p. 255). This may be the side of the self that is hidden to others and partly to our conscious self as well. And it is perhaps just because music "is not really translatable into words" that it "digs into our depths and expresses hidden movements of love and fear and joy that are inside us" (p. 254). Even the founder of modern rationalism, Descartes, must have experienced something like this. When he was 22 years old he wrote a small "Compendium of music", which has these opening lines: "Its object is sound. Its end is to delight and to elicit different affects in us" (Descartes 1978/1656, my transl.). ${ }^{6}$

After a discussion of different views on music and emotions, Nussbaum concludes that though music is different from language, it is a symbolic structure, which contains emotional material "embodied in peculiarly musical forms" (Nussbaum 2001, p. 265) that may be understandable for the listener who is familiar with the tradition that the music belongs to. Therefore a musical artwork can function in the same way to the listener as a tragedy to the spectator.

The spectator's emotions are ... real emotions, of a complex sort. They include emotions such as fear and pity and grief assumed through empathy with a perspective or perspectives embodied on the work; sympathetic emotions responding to the presence of those structures in the work; closely connected emotions about human life in general and about her own possibilities; and, finally, emotions of wonder and delight that take the artwork itself as their object. (Nussbaum 2001, p. 278)

Her main example is the first and fifth of Gustav Mahler's Kindertotenlieder. The poems were written in 1833 by Friedrich Rückert, a professor of Oriental languages, shortly after two of his children had died of scarlet fever. The songs exemplify that "the expressive power of the work does not reside in the text alone" (p. 280). The text itself may be interpreted as a consolation of the parent that the children are resting in God's hands. Mahler's music, however, seems not to give assurance to this interpretation. And

\footnotetext{
5 unbedingte Zuverlässigkeit in Dingen der Vernunft und Menschenwürde ...(p. 17).

${ }^{6}$ Compendium musicae Renati Cartesii. Hujus objectum est sonus. Finis ut delectet, variosque in nobis moveat affectus ...
} 
Nussbaum interprets the songs in this way: "For the children it is a sleep not of comfort but of nothingness. For the parent, it is the knowledge of the impossibility of any loving, any reparative effort." (p. 293) Face to face with death there is no hope.

Can this be an upbuilding example? I think so. It opens for empathy with the feelings of grieving parents. And it challenges us to converse about how we understand death, how we should show compassion with others and how we should be prepared ourselves.

Why should those who struggle with themselves as exemplars for children study works of art? Both Kantians and Aristotelians underline the importance of examples. Especially in the latter tradition works of art may be seen as unique cases, metaphors of basic attitudes to life and death - also unsayable aspects of our existence, cases which engages both our head and our heart. We may find some possible examples to emulate and many examples to reflect on and learn from. The experiences of artists can modify our own previous experiences, and each interpretation of a work of art is in itself a practice in the judgement of a unique situation. However, the promising possibilities in the study of art works are only possibilities. There is no guarantee that the upbuilding possibility is actualized.

\section{How Could Upbuilding Examples be Studied?}

I consider the study of upbuilding examples as a difficult and challenging process, an artistic process, a process where conversations in a group may be helpful, a process which in itself should express the aims of wisdom and love. With Kierkegaard's indirect communication as a model, I propose upbuilding studies as a bottom-up approach initiated by enthusiasts in informal self-governed pedagogical groups, who can get help from a database containing selected works of art.

"All you need is love ... It's easy" was the message on the 25th of June 1967, in the first TV program sent around the whole world by satellite (Beatles 1967). But is it really easy to love, is it easy "to learn how to be you in time", or always to "be ... where you're meant to be", as the Beatles proclaimed in their song? Upbuilding presupposes that "the love which we (for instance as educators) give to others (the children) is a gift that we ourselves have been given" (Tubbs 2005; Wivestad 2011, p. 620). This humiliating condition implies a Socratic doubt in oneself and in one's own doubt. The wisest person acknowledges that only the eternal wisdom can be perfect, as Socrates may have said in his Apology (23a). Kierkegaard maintains that "the world can be possessed only by its possessing me" (Kierkegaard 1990, p. 164), and understands our life as human beings in this way: Because the temporal, which we are possessed by, contradicts the eternal, which is our foundation, one's soul or self becomes "the contradiction of the temporal and the eternal" (p. 163).This means that we have to struggle, not only with the temporal side, but with the eternal side of our self as well. This struggle is not easy. The more we are able to control our temporal side, the more we are tempted to forget our limitations-forget to doubt our own doubt and forget that our life is a gift.

In all struggles with ourselves the task is to imagine different possibilities, deliberate alternatives in detail, choose the seemingly best ones and try them out in practice. It is not just a process of practical application of theoretical principles. It may rather be seen as an artistic process: "a halting and exploratory effort to give form to a vision" (Eisner 1979, p. 135). Reflections at each moment of halting are important, firstly in order to see the details of the "picture" as means to realise the vision, and secondly in order to see each new detail as a unique contribution that can clarify and modify the vision (the whole picture). 
Upbuilding examples can of course be studied individually, but conversation with others may be helpful. We can be taught moral and intellectual virtues "by having our reasoning put to the question by others, by being called to account for ourselves and our actions by others" (MacIntyre 1999, p. 148). If the starting point for a dialogue is the reading of an academic text or the listening to a lecture, there is a danger that the dialogue never starts, or becomes abstract and uncommitted. And if a group directly confronts the personal experiences of the participants, there is a danger that the conversation becomes too personal for some in the group. However, when all have experienced the same picture or film and discuss the examples in the work, it may be possible for the participants to find connections to their personal experiences and at the same time feel free to choose how much of their own experiences they want to share with the others.

As adults we are responsible for what we transfer to the next generation both when we do have pedagogical intentions and when we do not have such intentions. And the examples we give the children will probably have greater effect than the principles that we intentionally try to inculcate. "In human actions and emotions, where experience is most important, examples move us more than words" (Aquinas 2005, I-II 34,1 co., my transl.). ${ }^{7}$ The main themes in a pedagogical study of works of art could therefore be how we actually are and how we ought to be ourselves. ${ }^{8}$ If upbuilding examples in works of art are studied in a group, the participants may become exemplars for each other. In his essay "Learning and teaching" Oakeshott $(1967$, p. 176) uses this metaphor: "Not the cry, but the rising of the wild duck impels the flock to follow him in flight."

The process in such pedagogical groups should itself express the aims of moral wisdom and unconditional love. This implies openness, humility, and willingness to use necessary time in search for consensus and for solving conflicts. Conflicts are inevitable, but here they should not be seen as "disturbances", but as "actual possibilities for development of social attitudes and abilities" (Klafki 1996, p. 265, my transl.) . ${ }^{9}$ Moreover, as Kierkegaard lets us imagine, when love inhabits the heart, one closes the ears to mockery of oneself, gives hasty words of others a good meaning, has patience in listening to others, translates

\footnotetext{
7 In operationibus enim et passionibus humanis, in quibus experientia plurimum valet, magis movent exempla quam verba.

8 The themes that may be relevant for a particular group cannot be decided on beforehand, and the themes below (derived from Aristotle, Kierkegaard, Freire and Aquinas) sketches only some possibilities: The human condition (lack of freedom, oppression, ignorance, ...). The good life. Lack of character, the breaking of elementary laws, rules and promises (Bruno in L'Enfant). Outward punishments and rewards, consequences for the person (Huxley's Brave new world). Feelings of shame (inward punishment). Selfdirected search for better actions (Baard in A happy boy). Incontinence, weak character, with need of support from others in difficult situations (Louisa in Hard times). Continence (strong character), with dangers of hypocrisy, pedantry and bad feelings (Eyvind in A happy boy, the eldest brother in Rembrandt's The return of the prodigal son). Excellence or virtue, where thinking and emotions play together (Sissy Jupe in Hard times). The interdependence of all the virtues-lack of justice makes moderation and courage dangerous, and lack of moral wisdom makes inventiveness and cleverness dangerous (Bruno in L'Enfant). Friendship (conditional love) with willingness to do good things to loveable persons. Struggle with one's self to avoid being obsessed with passion for mastery and power (Eyvind in A happy boy). Struggle between the first self and the deeper self (Vasarely's Catch). Gaining and losing one's soul. Human action, roles, choice, the final end. The human good. Transformation of the person by God's grace and gifts (Kierkegaard's discourses). Unconditional love, agape, and its fruits: compassion, kindness, caring, inward and outward peace, joy (Alyosha in The brothers Karamazov). Injustice, solidarity and justice. Structures, rules and habits in society and culture that impede wisdom and love (Hard times, Pink Floyd's The wall). Ordering of a disordered character: Love of self disperses the person's emotions (Baard). Moderation and courage order us in ourselves. Justice orders us to others. Faith, hope and agape order us to God (Aquinas 1989, pp. 252-253, 2005, I-II 72,4 co.).

9 Anlaß zur Entwicklung von sozialen Einstellungen und Fähigkeiten ...
} 
evil words to good words, does not understand the speech of anger, because one waits for a word that will make the speech meaningful; gives without looking for rewards, looks for the good sides of others and loves forth the good even in the other who hurts one (Kierkegaard 1990, pp. 60-61).

Many types of groups could be possible. The most important factor is probably that one or a few persons believe in the idea, take initiatives and develop a suitable structure. Reading groups have functioned like this for many years. And though it is unlikely that such groups will attract the great majority, it can have great positive consequences if only a few persons in a local community start struggling with themselves. In the beginning of the novel Lienhard und Gertrud, Pestalozzi retells a story from a Jewish Rabbi:

"There were amongst the heathen nations who dwelt round about the inheritance of Abraham, men full of wisdom, whose equals were not to be found far or near. These said: 'Let us go to the kings and to their great men, and teach them how to make the people happy upon the earth.'

And the wise men went out, and learned the languages of the houses of the kings and of their great men, and spoke to the kings and to their great men, in their own language.

And the kings and the great men praised the wise men, and gave them gold, and silk, and frankincense; but treated the people as before. And the wise men were blinded by the gold, and the silk, and the frankincense, and no longer saw that the kings and the great men behaved ill and foolishly to all the people who lived upon the earth. But a man of our nation reproved the wise men of the heathens, and was kind to the beggar upon the highway; and took the children of the thief, of the sinner, and of the exile, into his house; and saluted the tax-gatherers, and the soldiers, and the Samaritans, as if they had been brethren of his own tribe.

And his deeds, and his poverty, and the longsuffering of his love towards all men, won him the hearts of the people, so that they trusted him as a father. And when the man of Israel saw that all the people trusted him as a father, he taught the people wherein their true happiness lay; and the people heard his voice, and the princes heard the voice of the people" (Pestalozzi 1825, pp. vi-viii).

The story can help us to see our own situation as "wise" academics who start our work with good intentions. We concentrate on mastering theoretical perspectives and the power structures that support them and benefit from them; we master the "languages" of the powerful. But thereby we risk forgetting our intention: to contribute to "make the people happy". A better way is to start in practice, in direct relation with people, acting in a way that is trustworthy. Then some people may listen and start to seek what gives true happiness. And those who have power must in the long run listen to the people, if they want to retain their power. Persons like Pestalozzi and Gandhi (Attenborough 1982) have followed the example of "the man of Israel", and the stories about them still have a great effect.

There are at least four reasons why pedagogical groups ought to be informal, even when the groups functions within formal educational structures:

1. The process of upbuilding and the examples we give the children are related to all situations of life. Many of the situations where adults are close to children are informal. Even formal education has informal sides, for instance the way the teacher and the students look upon each other and talk with each other both in and after the class. 
2. The groups should be led by informal leaders, not professionals. In "communities of giving and receiving" (MacIntyre 1999, p. 147) all participants are dependent on each other, and roles ought to change.

3. Using the rhetoric of Kierkegaard's discourses as a model, no one has a formal authority, and each participant should engage directly with the challenges in the works they study: enter a dialogue with the work, identify with different possibilities (characters and figures) in the work, recognise his or her own questions, deliberate the possibilities, and decide and actualize "a particular insight or value" (Pattison 2002, pp. 153-155).

4. Meeting informally will solve the practical problem of using films on video and DVD published only for use in homes.

As pedagogical groups, the studies are connected to paideia, i.e. upbringing, cultural inheritance and Bildung. Studies in a pedagogical group will be most meaningful when the content in the meetings hang together, and when each meeting is integrated in the life of the participants. Therefore the content should be organised as themes with a progressive differentiation. The ideal is that later studies should only be a particular evolution of what has been previously studied, like a tree with a permanent stem and main branches, which rambles in always new shoots (Comenius 1968, chap. 16, 45). ${ }^{10}$ Each theme should be related to the experiences of the participants. Therefore a group could start with elementary existential questions, like for instance "Why do we want children?" and with elementary themes, like for instance "The good life", and choose works that may be interesting for the actual group.

Imagine a group of adults, who study a picture like Catch, a text like A happy boy or a film like L'Enfant. They discuss their experiences and try to understand themselves-both how they are and how they want to become. It could be a student group in education or ethics, it could be a group of ice-hockey coaches or it could be a group of adults who live in the same neighbourhood, or have children in the same kindergarten or school or congregation. The group is planning its own studies, but in order to get ideas and help, they use an Internet database called Upbuilding examples: Pictures, films, music and texts for adults close to children. To give an inkling of how this could look like, I will mention a database which has been used in medical education since 1993: Literature, Arts and Medicine database http://litmed.med.nyu.edu. It contains annotations of works of art, films and literature; each work presented by searchable keywords, a summary and a commentary. See for instance the list of works connected by the keyword "Parenthood". A pedagogical database could include some of the same works, but the perspective would be different.

In my vision of a future database named Upbuilding examples, the main criteria for the selection of works of art would be the work's possible upbuilding qualities, its possible relevance for the participants in the group and its degree of difficulty.

What is upbuilding has been discussed in the second part of this article. An example may be a novel like Dickens' Hard times, where the utilitarian and cognitivist character Thomas Gradgrind is contrasted with the loving and serving Sissy Jupe. As mentioned, we have to consider whether this work is unique, appeals to our senses and feelings and contains something general that makes it possible for many people to recognise themselves in the work. Thereby individual personal experiences may be actualised. Can the work help us to recollect experiences we have "forgotten", experiences that we need to reflect upon

$10 \ldots$ tantum sint priorum particularior quaedam evolutio. Ita enim arbori... nulli novi rami enascuntur, sed primo enati in novos semper ramusculos diffunduntur. 
so that we can make "amends" (Dickens 1989, p. 314) for previous wrongdoings? This applies both to the life story of the individual and to the history of the generations in our culture. One's own story is a part of a bigger story. Through a work with upbuilding examples, one may become more conscious of one's own experiences and have a share in the experiences of others. One may see persons and situations in a new way, understand the feelings and the life of others, explore special situations that may come in the future and be prepared for them.

Acknowledgments I would like to thank Kristján Kristjánsson, Gert Biesta, Andrew Krivak, Peter Robins, Trygve Bergem, Nigel Tubbs, René V. Arcilla, Tone Sævi, Svein Rise, Herner Sæverot and Solveig M. Reindal for encouragement and constructive criticisms. I am also thankful to Michele Vasarely for permission to use Victor Vasarely's work Catch.

Open Access This article is distributed under the terms of the Creative Commons Attribution License which permits any use, distribution, and reproduction in any medium, provided the original author(s) and the source are credited.

\section{References}

Aquinas, T. (1989). Summa theologiae: A concise translation (T. McDermott, Trans.). Allen, Texas: Christian Classics.

Aquinas, T. (2005). Summa theologiae. Corpus Thomisticum S. Thomae de Aquino opera omnia. http://www.corpusthomisticum.org/iopera.html. Accessed 10 August 2012.

Arcilla, R. V. (2010). Mediumism: A philosophical reconstruction of modernism for existential learning. Albany, NY: SUNY Press.

Aristotle. (1985). Nicomachean ethics (T. Irwin, Trans.). Indianapolis, Ind.: Hackett.

Aristotle. (1997). The politics of Aristotle (P. L. P. Simpson, Trans.). Chapel Hill: University of North Carolina Press.

Aristotle. (2002). Nicomachean ethics (C. J. Rowe, Trans.). Oxford: Oxford University Press.

Attenborough, R. (1982). Gandhi [DVD, 183 min.]. USA: Columbia Tristar, 2001.

Bach, J. S. (1731). Concerto for 2 violins, strings and continuo in d minor, BWV 1043. http://www.youtube.com/watch?v=3ZmfgBoZytw. Accessed 10 August 2012.

Beatles. (1967). All you need is love. http://www.lyricsfreak.com/b/beatles/all+you+need+is+love_ 10026698.html. Accessed 10 August 2012.

Biesta, G. (2012). Receiving the gift of teaching: From 'learning from' to 'being taught by'. Studies in Philosophy and Education, doi:10.1007/s11217-012-9312-9.

Bjørnson, B. (1860/1896). A happy boy (W. Archer, Trans.). London: William Heinemann.

Campbell, M. (2006). Casino Royale [DVD, 139 min.]. Sony Pictures Home Entertainment.

Comenius, J. A. (1968). Magna didactica: Ex editione Amstelodamensi anni 1657 omnes libros didacticos complectente, nunc primum separatim editit Fridericus Carolus Hultgren, Lipsiae [Leipzig] 1894. Farnborough, UK: Gregg.

Comenius, J. A. (1986). Comenius's Pampaedia or universal education (A. M. O. Dobbie, Trans.). Dover: Buckland Publications.

Dardenne, J.-P., \& Dardenne, L. (Directors). (2005). L'enfant [DVD, 100 min.]. Belgium/France: Sony Pictures Classics (USA).

Descartes, R. (1978/1656). Leitfaden der Musik/Musicae compendium (J. Brocht, Trans.). Darmstadt: Wissenschaftliche Buchgesellschaft.

Dewey, J. (1988). Experience and education. In J. A. Boydston \& B. Levine (Eds.), The later works, 19251953 (Vol. 13: 1938-1939, pp. 1-62). Carbondale and Edwardsville, IL: Southern Illinois University Press.

Dickens, C. (1989). Hard times. Oxford: Oxford University Press.

Dostoevsky, F. M. (2000). The brothers Karamazov. In J. Manis (Ed.). http://www2.hn.psu.edu/faculty/ jmanis/dostoevs/karamazo.pdf. Accessed 10 August 2012.

Dylan, B., \& Arnosky, J. (2010). Man gave names to all the animals [Picture book with CD]. New York: Sterling. 
Eisner, E. W. (1979). The educational imagination: On the design and evaluation of school programs (1st ed.). New York: Macmillan.

Eisner, E. W. (1991). The enlightened eye: Qualitative inquiry and the enhancement of educational practice. New York, NY: Macmillan Publ. Co.

Freire, P. (1972). Pedagogy of the oppressed. Harmondsworth: Penguin.

Friesen, N., \& Sævi, T. (2010). Reviving forgotten connections in North American teacher education: Klaus Mollenhauer and the pedagogical relation. Journal of Curriculum Studies, 42(1), 123-147.

Gadamer, H.-G. (1965). Wahrheit und Methode: Grundzüge einer Philosophischen Hermeneutik (2nd ed.). Tübingen: Mohr.

Gadamer, H.-G. (1979). Truth and method (W. Glen-Doepel, J. Cumming \& G. Barden, Trans. 2nd ed.). London: Sheed and Ward.

Gadamer, H.-G. (1986). The relevance of the beautiful: Art as play, symbol and festival (N. Walker, Trans.). In R. Bernasconi (Ed.), The relevance of the beautiful and other essays [by] H.-G. Gadamer (pp. 3-53). Cambridge: Cambridge University Press.

Guyer, P. (2012). Examples of moral possibility. In K. Roth \& C. W. Surprenant (Eds.), Kant and education: Interpretations and commentary (pp. 124-138). New York: Routledge.

Hadot, P. (1995). Philosophy as a way of life: Spiritual exercises from Socrates to Foucault. Oxford: Blackwell.

Jagger, M., \& Richards, K. (1965). I can't get no satisfaction [song]. In the album Out of our heads. USA.

Kierkegaard, S. (1990). Eighteen upbuilding discourses (E. H. Hong \& H. V. Hong, Trans.). Princeton, New Jersey: Princeton University Press.

Kierkegaard, S. (1995). Works of love (H. V. Hong \& E. H. Hong, Trans.). Princeton, N.J.: Princeton University Press.

Kierkegaard, S. (2010). Spiritual writings: Gift, creation, love: Selections from the upbuilding discourses (G. Pattison, Trans.). New York, NY: Harper Perennial.

Kieslowski, K. (1988). Dekalog: The ten commandments [DVD, four discs]. Poland: World Cinema.

Kieslowski, K. (1993). Trois couleurs: Bleu [DVD, 94 min.]. Scanbox Entertainment Norway.

Klafki, W. (1996). Neue Studien zur Bildungstheorie und Didaktik: Zeitgemäße Allgemeinbildung und kritisch-konstruktive Didaktik (5th ed.). Weinheim: Beltz.

Kon, S. (2003). Tokyo godfathers [DVD, 90 min.]. Japan: Sony Pictures Entertainment.

Louden, R. B. (2009). Making the law visible: The role of examples in Kant's ethics. In J. Timmermann (Ed.), Kant's Groundwork of the metaphysics of morals: A critical guide (pp. 63-81). Cambridge: Cambridge University Press.

Løvlie, L. (1997). The uses of example in moral education. Journal of Philosophy of Education, 31(3), 409-425.

MacIntyre, A. (1999). Dependent rational animals: Why human beings need the virtues. London: Duckworth.

Mann, T. (1980). Doktor Faustus: Das Leben des deutschen Tonsetzers Adrian Leverkühn erzählt von einem Freunde. Frankfurt am Main: S. Fischer.

Mollenhauer, K. (1994). Vergessene Zusammenhänge: Über Kultur und Erziehung (4th ed.). München: Juventa Verlag.

Munch, E. (1893). Skrik [The scream] (Casein/waxed crayon and tempera on cardboard, $91 \mathrm{~cm} \times$ 73,95 cm). National Gallery, Oslo.

Nussbaum, M. C. (2001). Upheavals of thought: The intelligence of emotions. Cambridge: Cambridge University Press.

Oakeshott, M. (1967). Learning and teaching. In R. S. Peters (Ed.), The concept of education (pp. 156-176). London: Routledge \& K. Paul.

Pattison, G. (2002). Kierkegaard's upbuilding discourses: Philosophy, literature, theology. London, New York: Routledge.

Perkins, R. L. (2003). Introduction to Eighteen upbuilding discourses (Vol. 5, pp. 1-14). Macon, Ga.: Mercer University Press.

Pestalozzi, J. H. (1825). Leonard and Gertrude or a book for the people: Translated from the German of Pestalozzi (Vol. 1-2). London: J. Mawman, Ludgate Street.

Pink-Floyd. (1979/1994). The wall [Concept album]. United Kingdom: EMI.

Plato. (1966). Euthypro, Apology, Crito, Phaedo (H. N. Fowler, Trans.). Plato in twelve volumes (Perseus 4.0 ed., Vol. 1). London: Heinemann. http://www.perseus.tufts.edu/hopper/text?doc=Perseus:text: 1999.01.0170. Accessed 10 August 2012.

Plato. (2000). The republic (T. Griffith, Trans.). Cambridge: Cambridge University Press.

Rembrandt, H. v. R. (1668). The return of the prodigal son (Oil on canvas, $262 \times 205 \mathrm{~cm}$ ). St. Petersburg: State Heremitage Museum. 
Samuel, V. (2007). Staying calm with your kids. http://supernanny.com/Advice/-/Your-child/-/Childcare/Staying-calm-with-your-kids.aspx. Accessed 10 August 2012.

Small, C. (1996). Music, society, education. Hanover, NH: Weyslean University Press.

Søltoft, P. (2000). To let oneself be upbuilt. In N. J. E. Cappelørn, H. E. Deuser, \& J. E. Stewart (Eds.), Kierkegaard studies: Yearbook 2000 (pp. 19-39). Berlin: Walter de Gruyter.

Tubbs, N. (2005). Special Issue-Philosophy of the teacher. Journal of Philosophy of Education, 39(2), 183-420. (I refer to the paper version. The electronic version covers the same content on pp. 183-414).

Vasarely, V. (1982). Gea. Paris: Hervas.

Wivestad, S. M. (2008). The educational challenges of "agape" and "phronesis". Journal of Philosophy of Education, 42(2), 307-324.

Wivestad, S. M. (2011). Conditions for 'upbuilding': A reply to Nigel Tubbs' reading of Kierkegaard. Journal of Philosophy of Education, 45(4), 613-625.

Wivestad, S. M. (2012). On becoming better human beings: Six stories to live by. Studies in Philosophy and Education, doi:10.1007/s11217-012-9321-8. Online first. Open access.

Zapffe, P. W. (1983/1941). Om det tragiske. Oslo: Aventura. 